http://dx.doi.org/10.12775/szhf.2018.018

\author{
MieczysŁaW WALLIS
}

\title{
Wspomnienia o Janie Łukasiewiczu
}

Materiały Archiwalne Mieczysława Wallisa, Archiwum Połączonych Bibliotek Wydziału Filozofii i Socjologii Uniwersytetu Warszawskiego, Polskiej Akademii Nauk i Polskiego Towarzystwa Filozoficznego w Warszawie, teczka Rps nr 10, T. IX.

\section{k. 77}

\section{Łukasiewicz}

Przyglądając się temu drobnemu, szczupłemu, niepozornemu, porządnie, lecz skromnie ubranemu panu na ulicy w miękkim filcowym kapeluszu, z laseczką, którą, idąc, rytmicznie podnosił i opuszczał, trudno było odgadnąć, że jest on twórcą rewolucyjnych koncepcji w dziedzinie logiki, metodologii, teorii prawdopodobieństwa, historii logiki. Tylko jego małe, szczurze oczy, para pince-nez, iskrzyły się od inteligencji.

k. 70

\section{Jan Lukasiewicz Entuzjasta logiki matematycznej}

Dla Łukasiewicza logika matematyczna nie była jednym z kierunków logiki współczesnej: była logiką w nowoczesnej postaci, poza którą nie było innej logiki naukowej. 


\section{k. 71}

\section{Jan Lukasiewicz}

Łukasiewicz stał się wielkim historykiem logiki, zwłaszcza logiki greckiej, dzięki temu, że łączył świetną znajomość oryginalnych tekstów greckich ze znajomością współczesnej logiki matematycznej.

\section{k. 78}

\section{Wsp. Uniw. Warsz.1916-1921 Łukasiewicz}

W początku stycznia 1916 r. wróciłem do Warszawy. W końcu marca tego roku zacząłem studiować filozofię u Jana Łukasiewicza i Władysława Tatarkiewicza na świeżo wówczas otworzonym polskim Uniwersytecie Warszawskim. Przeskok od Heidelberga do Warszawy był olbrzymi. Znalazłem się w zupełnie innym „klimacie intelektualnym”. Łukasiewicz, uczeń Kazimierza Twardowskiego we Lwowie, mający za sobą również studia na uniwersytecie katolickim w Lowanium, autor przełomowej pod pewnymi względami pracy „O zasadzie sprzeczności u Arystotelesa”, umysł jasny i ścisły, wykładał filozofię Leibniza i czytał z nami w seminarium „Badania” Hume’a i „Prolegomena” Kanta, przede wszystkim jednak propagował - logikę matematyczną. Kanta odsądził od czci i wiary, odmawiał mu jakiejkolwiek wartości naukowej. Czytanie „Prolegomenów” pod jego kierunkiem było jakąś ekspedycją [...] przeciw Kantowi, wydobywaniem wszystkich popełnionych przez niego błędów logicznych i nieścisłości. Dopiero znacznie później zrozumiałem głębsze podłoże tej niechęci do Kanta. Łukasiewicz nie lubił Kanta nie tylko z powodu niepoprawności logicznych jego dzieł. Poprzez Twardowskiego wiązał się on z Franciszkiem Brentanem, z austriacką szkołą filozoficzną. W szkole tej zaś jak powiada Gerhard Lehmann „niechęć do Kanta była tradycyjną”. Filozofia austriacka wychowana na katolicyzmie nie znosiła protestanckiego Kanta. Windelband widział w Kancie jednego największych myślicieli wszystkich czasów, w jego systemie - najbardziej oryginalny wkład filozofii nowożytnej. Łukasiewicz Kanta traktował en canaille ${ }^{1}$, stawiał go znacznie niżej od Leibniza. Windelband twierdził, że istnieją wprawdzie logiczne zasady matematyki, lecz nie ma matematycznych zasad logiki. Dla Łukasiewicza logika matematyczna była nie tylko najdoskonalszą z nauk, ale również środkiem naprawy filozofii. Pod każdym względem kontrast był zupełny. Lecz właśnie ten kontrast pobudzał do myślenia.

${ }^{1} \mathrm{Z}$ jęz. fr. pogardliwie, z góry. 
k. 8

\section{Wsp. Warszawa 1916/1918 Metodologia humanistyki}

Początkowo usiłowałem opierać się wpływowi Łukaszewicza. Windelband, zwłaszcza jako historyk filozofii, wydawał mi się bez porównania głębszy. Później jednak musiałem uznać oryginalność i solidność wielu pozycji Łukasiewicza. Mimo to jeszcze długo żyłem w kręgu zagadnień wyniesionych z Heidelberga. Zimą 1916 r. przeczytałem odeski do deski „Krytykę czystego rozumu”. Ostateczny jej wynik -twierdzenie, że możemy poznawać jedynie „zjawiska”, natomiast rzeczywistość, jaką ona jest, niezależnie od naszego umysłu, świat „rzeczy samych w sobie” jest i będzie dla nas wiecznie niepoznawalny - był dla mnie przygnębiający szukałem jakiejś drogi, która by mimo wszystko prowadziła do tego świata. Windelband wskazywał na to, że Kant uwzględniał jako poznanie naukowe tylko matematykę i przyrodoznawstwo. Może teoria poznania [powinna wciąga [ć] ${ }^{2}$ w zakres swych rozważań również humanistykę.

k. 79

Wsp. Uniw. Warsz.1916-1921 Łukasiewicz

Ł. [ukasiewicz] ${ }^{3} \mathrm{w}$ tym czasie interesował się jeszcze zagadnieniami teorii bytu, zwłaszcza zagadnieniem wolności woli. Podobnie jak młodego Fichtego nękało go widmo świata całkowicie zdeterminowanego przyczynowo. Szukał argumentu przeciw determinizmowi i sądził, że ten argument znalazł w niemożności stosowania praw ogólnych do przedmiotów jednostkowych, które nigdy całkowicie pod te prawa nie podpadają. Myśl tę wyłożył nam w swym wykładzie pożegnalnym - zdaje się wczesną wiosną 1918 r., gdy został powołany na szefa Sekcji Szkół Wyższych w Ministerstwie Oświaty przy ówczesnej Radzie Regencyjnej. [...]

Z biegiem czasu filozofia tradycyjna coraz mniej zadowalała Łukasiewicza. Russell twierdził (we wstępie do „Wykładu filozofii Leibniza”), że błąd występuje zwłaszcza w postaci niekonsekwencji logicznej. Podobnie Łukasiewicz głosił, że każdy system filozoficzny musi się przede wszystkim wylegitymować przed forum logiki. Wyniki takiego sądu nad systemami filozoficznymi były żałosne. Każdy z nich okazywał się zbiorem najbardziej prymitywnych błędów logicznych: sprzeczności, wieloznaczności, błędnych kół w dowodzeniu.

\footnotetext{
${ }^{2}$ Uzupełnienie autorskie.

${ }^{3}$ Uzupełnienie autorskie.
} 


\section{k. 84}

\section{Wsp. Uniw. Warsz.1916-1921 Łukasiewicz a Kant}

Według Kanta „rzeczy same w sobie” przechodząc przez środowisko naszego umysłu z jego „formami oglądu” i „kategoriami” ulegają zniekształceniu. Nie poznajemy przeto nigdy „rzeczy samych w sobie”, lecz jedynie „zjawiska".

Różnorakie zarzuty wysuwane przez Łukasiewicza przeciw temu poglądowi Kanta.

I. Skąd Kant wie, iż „rzeczy same w sobie”, przechodząc przez środowisko naszego umysłu, ulegają zniekształceniu? Ażeby to stwierdzić, musielibyśmy mieć możność porównania „zjawisk” z „rzeczami samymi w sobie", tymczasem, według Kanta, to właśnie jest niemożliwe.

II. Istnienie sądów syntetycznych a priori w matematyce i „czystym przyrodoznawstwie" jest dla Kanta następstwem, do którego dobiera on racje w postaci istnienia „form oglądu” i „kategorii”. Mamy tu, zgodnie z przyjętym przez Łukasiewicza podziałem rozumowań, „rozumowanie redukcyjne". W rozumowaniach redukcyjnych z pewnością następstwa może, ale nie musi się łączyć pewność racji.

III. Według współczesnej teorii matematyki (Russell?) nie ma w ogóle w matematyce sądów syntetycznych: wszystkie sądy matematyczne są sądami analitycznymi. Zagadnienia, jakie Kant sobie stawia: ,jak są możliwe syntetyczne sądy a priori?" jest przeto zagadnieniem pozornym.

IV. Dzieła epistemologiczne Kanta, „Krytyka czystego rozumu” i „Prolegomena" roją się, podobnie jak dzieła innych filozofów, Spinozy lub Hegla, od błędów logicznych - nieścisłości, niekonsekwencji, sprzeczności, błędnych kół w rozumowaniu itp.

Opracowała Joanna Dorota Zegzuła-Nowak Uniwersytet Zielonogórski, Zielona Góra, Polska e-mail: joanna_zegzula@vp.pl 